\title{
Neodesenvolvimentismo e novas modalidades de degradação do trabalho no Brasil
}

ALVES, Giovanni. Trabalho e neodesenvolvimentismo: choque de capitalismo e nova degradação do trabalho no Brasil. Baurú: Canal6, 2014. 220p.

Elsa Cristine Bevian

PPGICH/Universidade Federal de Santa Catarina \& CCJ/Universidade Regional de Blumenau

Trabalho e neodesenvolvimentismo: choque de capitalismo e nova degradaça do trabalho no Brasil, de Giovanni Alves, é uma obra formativa, esclarecedora e, ao mesmo tempo, instigante. $\mathrm{O}$ autor apresenta o livro em três partes: a nova degradação do trabalho no Brasil, choque de capitalismo e neodesenvolvimentismo no Brasil, e precariado e proletaróides: espectros da proletariedade no Brasil. A seguir se examinam alguns de seus aspectos que mais destacam.

Alves parte do pressuposto básico de que a precariedade no trabalho é um traço estrutural da produção capitalista. Afirma que nos trinta anos perversos do capitalismo global (1980-2010) ocorreram dois fatos significativos que incidiram sobre a forma de ser histórica da precarização do trabalho: o surgimento da maquinofatura, produto das revoluções tecnológicas do capitalismo tardio (revolução informática e revolução informacional) e, a partir de meados da década de 1970, o desenvolvimento da crise estrutural do capital. A crise se explicaria pelo aumento da composição orgânica do capital e pela queda da taxa média de lucros, provocando múltiplos movimentos contra-tendenciais, que impulsionaram a reestruturação capitalista nas diversas instâncias da vida social - economia, política, cultura, trabalho, sociabilidade etc.

A maquinofatura, que se constituiu a partir da nova base tecnológica, possibilitou a captura da subjetividade do ser humano por meio do espírito do toyotismo, afetando profundamente o processo de reprodução social do trabalho vivo. Alteraram-se os termos de estranhamento social, dado pela relação tempo de vida/ tempo de trabalho, pela constituição do modo de vida just-in-time.

A partir da maquinofatura desenvolveu-se a sociedade de serviços, caracterizada pela vigência do trabalho ideológico, um modo de trabalho humano concreto que 
implica a ação comunicativa sobre outros homens e sobre si mesmo. Ou seja: trabalho ideológico com implicação estranhada, tendo na gestão o veículo de estranhamento. A gestão como doença social possui, segundo Alves, um sentido ideológico que estressa o sujeito-que-colabora. Como resultado, aumenta o risco de adoecimento laboral - a precarização-do-homem-que-trabalha.

No século XXI surgem novas formas de precarização do trabalho, que o autor denomina de precarização existencial, decorrente do modo de vida just-in-time, que produz vida reduzida e provoca carecimentos radicais nas pessoas que trabalham; e precarização radical do homem como ser genérico, a precarização do homem-que-trabalha, decorrente dos adoecimentos laborais. É o complexo de complexos da precarização estrutural do trabalho.

O modo de vida constitui o pressuposto da organização do trabalho, compreendendo as experiências de organização do tempo e do espaço no âmbito das instâncias de circulação (trajetos da vida urbana), distribuição e trocas (padrão de sociabilidade, relações sociais, valores e modos de autorreferência pessoal), e consumo (modos de percepção e gosto cultural, apropriação e aquisição de produtos, de acordo com necessidades sociais e carecimentos radicais). O modo de vida diz respeito à reprodução social, sendo objeto da regulação social pelas instituições. O modo de vida just-in-time corresponde à organização do modo de vida nas condições do capitalismo flexível.

O modo de vida just-in-time significa uma maior carga de pressão no plano psíquico dos trabalhadores, implicando no que Alves designa por vida reduzida. O capital limita a possibilidade de desenvolvimento humano-pessoal dos indivíduos sociais, na medida em que o tempo de vida disponível das pessoas está avassalado pela lógica do trabalho estranhado e pela lógica do consumismo desenfreado. A vida reduzida possui alguns traços característicos fundamentais: significa vida veloz, vida sinalizada, vida enxuta, vida capturada e vida invertida.

Por exemplo: vida capturada é vida manipulada, intensiva e extensivamente, nas mais diversas esferas da vida social. O sujeito capturado e que colabora debate-se, consciente e inconscientemente, consigo mesmo, resistindo à sua própria desefetivação humano-genérica. A vida redựida também é vida enxuta, na medida em que a vida das pessoas tende a se reduzir às partes necessárias à montagem das exigências sistêmicas. "Eu faço não o que me dá fruição de vida, mas sim o que tem utilidade para minha carreira profissional". A vida enxuta, no plano cotidiano, está permeada do pragmatismo existencial, invadindo o tempo livre ou o tempo disponível para si, reduzindo irremediavelmente o tempo disponível para as relações com amigos e familiares e, inclusive, para o cuidado de si. A crise de sociabilidade, ao reduzir o círculo de amizades, contribui para o fenômeno da vida enxuta.

A precarização existencial, do trabalho, salarial, os nexos causais das doenças do trabalho que degradam a pessoa humana, todos esses fatores, segundo Giovanni 
Alves, favorecem a deformação da personalidade humana. $O$ carecimento radical de sentido da vida humana parece insolúvel nas condições do prosaísmo da sociedade de mercadorias. É a barbárie social. Aí o autor se vale de Georg Lukács, que afirmou ser o capitalismo incapaz de oferecer uma vida plena de sentido. Com a intensificação do fetichismo da mercadoria nas condições históricas do capitalismo globalizado, com as forças do mercado invadindo, disruptivamente, a vida cotidiana das pessoas, intensificou-se a manipulação das instâncias do consumo, política e de produção da vida social. Com a disseminação da nova precariedade salarial e da precarização existencial, aprofundou-se o aviltamento da personalidade humana, que, por sua vez, tem contribuído para o surgimento do fenômeno do ensimesmamento, característica eloquente do estranhamento da vida social na era do capitalismo manipulatório.

As pessoas acabam mergulhando no mundo da solidão profunda do ser, aceitando a imediaticidade de sua condição de proletariedade, imposta pelo status quo, sem veleidade de "transcendência", e sem verdadeira aspiração de autodeterminação. Para que elas pudessem encontrar o sentido da vida, seria necessário que dito sentido fosse percebido: "Não se trata de injetar sentido nas coisas, mas sim de extrair o sentido delas, de captar de cada uma das situações com que nos defrontamos" (p. 32).

O conceito de pessoa humana não se restringe à dimensão da subjetividade, mas implica também o elemento da alteridade (dimensão da sociabilidade) e o elemento da individualidade (dimensão constitutiva da personalidade única do sujeito por meio de processos de socialização/individuação). Os indivíduos acabam se comportando como agentes da reprodução do todo estranhado, o que constitui o que chama de sociometabolismo da barbárie (p.38). Daí que o ser acaba, inevitavelmente, entrando em crise, crise de sociabilidade e de autorreferência humano-pessoal.

Apoiando-se em Richard Sennett, Alves lembra que o fenômeno da "corrosão do caráter" é produto da crise de sociabilidade, da redução dos espaços de socialização e espaços do self, eixos orgânicos da formação da personalidade humana. É aí, então, que conclui o que corresponde à primeira parte do livro, argumentando que a problemática crucial da questão social no século XXI radica na explicitação da contradição do capital, nomeadamente, entre desenvolvimento das capacidades humanas e degradação da personalidade humana. E este é o problema do estranhamento social.

Giovanni Alves ainda explora o problema do aumento significativo de adoecimento dos trabalhadores nas últimas décadas. Dialoga com Margarida Barreto para mostrar que as doenças do trabalho resultam da reestruturação do capital. Ele chama atenção, especialmente, para o fato de que os distúrbios psicossomáticos estão intimamente associados ao sofrimento decorrente da prática do assédio moral - incluindo insônia, síndrome do pânico, transtorno de 
ansiedade generalizado. Um dos principais medos - que dúvida - é o de perder o emprego, não apenas porque aí se comprometeria a fonte de renda pessoal/familiar, mas também porque o modo de manutenção do padrão de consumo ampliado ficaria ameaçado pela perda do acesso ao crédito e ao endividamento - ou seja, stress por meio da captura da subjetividade do trabalho.

Por fim, mas não menos relevante, cabe destacar o conceito de precariado, com o qual Giovanni Alves tem designado a nova camada da classe social do proletariado, recorrendo a demarcações categoriais bastante precisas no plano sociológico. Precariado, para ele, é a camada média de proletariado urbano precarizado, constituída por jovens-adultos altamente escolarizados, mas com inserção precária nas relações de trabalho e vida social.

Porque ler Trabalho e neodesenvolvimentismo: choque de capitalismo e nova degradação do trabalho no Brasil? Porque aí se encontra uma chave importante não apenas para que nos situemos - onde estamos? -, mas, também, para que pensemos em alternativas - para onde estamos indo? Isso não é pouco.

Endereço para correspondência:

ElsaCristine Bevian-elsa@furb.br

PPGICH/UFSC, Campus Universitário, Trindade

88040-900 Florianópolis/SC, Brasil 